\title{
Aziz ŞEKER
}

Dr. | Dr.

Dr. Sosyal Hizmet Uzmanı, Amasya Üniversitesi, Amasya-TÜRKIYY

Social Worker, Amasya University, Amasya-TURKEY

ORCID: 0000-0001-5634-0221

shuaziz@gmail.com

\section{Durkheim'in Sosyolojisinde İntihar ve İntiharla Mücadelede Sosyal Hizmetin İşlevi}

$\ddot{\mathbf{O} z}$

İntihar bir sosyal sorun haline dönüşmeye başladığından itibaren sosyal bilimin dikkatini çekmiştir. Zamanla intiharın nedenleri ve hangi etkenlerin ne tip intiharlara kaynaklık ettiğine yönelik araştırmalar yapılmış, intihara yönelik mücadelede çözüm yolları ve öneriler üzerinde durulmuştur. İntihar ile ilgili ilk geniş çaplı alan çalışmaları özellikle sosyoloji etrafında şekillenmiştir. Tıbbın yanı sıra, sosyal psikolojinin ve sosyal hizmet mesleğinin gelişimiyle intihar olgusuna bakışta yeni sosyal yaklaşımlar geliştirilmiştir.

$\mathrm{Bu}$ çalışmada günümüz toplumları açısından bir sosyal sorun haline gelmiş olan intihar konusu, Durkheim'ın bu olgu ile ilgili yaptığı çalışmasından yola çıkılarak analiz edilecek ve intihara yönelik çalışmalarda sosyal hizmet uygulamasının işlevi genel olarak irdelenip, birtakım öneriler üzerinde durulacaktır.

Anahtar Kelimeler: Durkheim, İntihar, Sosyoloji, Sosyal Hizmet.

\section{Suicide in Durkheim's Sociology and the Function of Social Work in the Struggle Against Suicide}

\begin{abstract}
Since suicide began to turn into a social problem, it has attracted the attention of social science. Several studies have been carried out on the causes of suicide and which factors cause which type of suicides and proposals have been put forward for the struggle against suicide. The first comprehensive field studies on suicide were shaped around sociology. With the development of medicine, social psychology as well as social work profession, new social approaches have been developed to understand the suicide phenomenon.

In this study, suicide which has become a social problem for today's societies will be analyzed based on the related studies of Durkheim, the function of social work practice will be examined in general in the studies on suicide and some proposals will be put forward.
\end{abstract}

Keywords: Durkheim, Suicide, Sociology, Social Work. 


\section{Giriş}

Durkheim sosyolojinin bir disiplin olarak ortaya çıkmasında ve sosyolojik düşüncenin gelişiminde önemli düzeyde etkili olmuş tarihsel figürler arasında yer alır. Durkheim'in sosyolojiyi bilimsel yaklaşıma taşıyan öncüler arasında anıtlaştırılmasının temel nedeni, sosyolojiye ilk defa kapsamlı bir bilimsel paradigma sağlamış olmasında yatmaktadır. Bu paradigma, sosyolojinin amacına dönük bir dizi teknik reçete sağlamaktan ziyade, toplumsal olgulara yaklaşım konusunda bütünlüğü bulunan bir yöntem sunmuştur. Onun yönteminin temel nitelikleri felsefeden bağımsız, nesneldir, toplumsal olguları toplumsal nesneler gibi ele alır. Yöntemindeki nedensellik ilkesinin toplumsal görüngülere uygulanması ve bir toplumsal olgunun ancak başka bir toplumsal olguyla açıklanabileceği görüşü en önemli özelliğidir (Ergun, 1982: 72; Tiryakian, 1997: 193, 241; Durkheim, 1985: 152). Burada sosyolojinin toplumsal olgulara nesnel yaklaşımı, sosyal hizmet araştırmasını ana yöntemlerinden biri kabul etmiş sosyal hizmet disiplinine de bir katkı olarak düşünülmelidir. Dolayısıyla toplumsal olguların anlaşılması için yapılan çalışmaların, uygulamalı bir disiplin olarak kabul edilen sosyal hizmetin teorik yapısını bu niteliğiyle güçlendirdiğinden şüphe etmemek gerekir.

Durkheim, Toplumsal İş bölümü kitabında mekanik ve organik dayanışma ile bu iki farklı olgunun hüküm sürdüğü toplumların özelliklerini vermekle birlikte, din ve hukuk gibi toplumsal kurumların gelişim süreçleri üzerine tartışmaktadır. Eserinde meslek örgütlerine ve iş bölümü kavramına ayrı bir yer ayırır. Ona göre; iş bölümü aracılığıyladır ki, birey topluma olan bağlılık durumunun bilincine varır; onu durduran ve sınırlandıran güçler toplumdan gelmektedir. İş bölümü toplumsal dayanışmanın önde gelen kaynağı olduğundan, aynı zamanda ahlak düzeninin de temeli olmaktadır. Bu açıdan iş bölümünün toplumsal dayanışmaya katkısına toplumsal koruma ve sosyal güvenlikten hareket ederek bakarsak, ona sosyal politika ve sosyal hizmetin amaçlarıyla örtüşecek biçimde bir işlev yüklediğini ifade etmek mümkündür. Diğer önemli bir kitabı Dinsel Yaşamın Illk Biçimleri'nde ise genel anlamda dinin, toplumun kuruluşundaki rolünü incelemiştir. Dini sosyolojik bir olgu halinde Avustralya'da yaşamış Arunta kabilesinden yola çıkarak çözümlemiş̧tir. Dinin ortaya çıkışında kolektif bilincin toplum için ne değin önemli olduğunu en basit şekil olan totemizm üzerinden yola çıkarak aktarmıştır. Dinle toplum arasındaki etkileşimi irdeleyen Durkheim, böylece sosyal 
teoride yapısal işlevselciliğin gelişiminde de belirleyici olmuştur (Durkheim, 2010: 23; 2014: 456).

Din zamanla birçok sosyal bilimcinin işlediği bir olgudur. Simmel bunlardan biridir. Simmel'in, dinsel pratikle ilişkili olarak sosyal hizmetin eski toplumlarda nasıl var olduğunu göstermesi açısından verdiği şu örneği anımsamakta yarar var: Eski Sami halkları arasında, yoksulların bir yemeğe katılma hakkı kişisel cömertliğin değil, toplumsal bağların ve dini adetlerin sonucudur. Yoksullara yapılan yardımın varlık nedeninin unsurlar arasındaki organik bir bă̆ olduğu yerlerde, dini öncülleri ister metafizik bir birlikten ister biyolojik bir birliğin ürünü olan akrabalık yahut kabile bağından kaynaklanıyor olsun, yoksulların hakları daha fazla vurgulanır (Simmel, 2009: 157). Sosyal hizmetin geleneksel alanlarından biri kabul edilen sosyal yardım tarihinde yoksullara insani yardım sunulması, toplumu bütünleştirici bir yana sahiptir. Dinin işlevleri arasında sosyal yardım teması incelendiğinde, dinin aynı zamanda sosyoloji ve sosyal hizmet disiplininin gelişim koşulları irdelendiğinde dikkate alınan bir olgu olduğu görülmektedir. Durkheim'in analiz biçiminin, yapısalcılığın gelişimine katkısından da kısaca burada söz etmek gerekir. Durkheim'in saptaması, öncesinde din ve kültür ilişkisini ilkel toplumlarda çözümlememizi kolaylaştırmakla işe başlamış olmasinda anlam bulur. Durkheim'e göre dinin toplumsal boyutu toplumun ortak tasarımları yansıtmasından ileri geldiği gibi diğer toplumsal kurumların ortaya çıkışında önemli bir kaynaktır. Toplumsal nedenlerin bir sonucu olarak gördüğü dinin, yapısal çözümü konusunda çalışan Durkheim'in kullandığ 1 içerik, kısmen kimi materyallerle Lewis'in Eski Toplum yapıtında totemciliğin örgütleniş biçimi üzerindeki çalışmalarıyla benzerlikler göstermektedir. Gerçi Lewis eski soy toplumlarındaki özgürlük, eşitlik ve kardeşlik günlerinin daha gelişkin bir halde yeniden hayata kazandırılmasında mülkiyet ve kullanımıyla toplumsal yapı arasındaki çelişki üzerinde dururken, toplumların tarihsel materyalizm açısından evrimini dikkate almıştır. Bunun yanı sıra Lewis, Doğu Yarıküresinde de, Batı Yarıüresinde de insanlığın aynı basit bilgi ve beceri düzeylerinden yola çıkarak uygarlaşma çabalarına başladığını; uygarlaşma sürecinde ileriye doğru aşılmış her dönemde bütün insan toplumlarının aynı güçlükler, aynı çözümler, aynı beceriler, aynı bilgi sistemleştirmeleri ve aynı örgütlenme biçimlerinden geçtiğini söylerken, birçok etnografik çalışmanın ortak benzerliklerine ve toplumsal varsayımlarına öngörü sağlamıştır (Morgan, 1986a: 405; 1986b: 9). 
Durkheim ise Dinsel Yaşamın Illk Biçimleri'nde Avustralya totemciliğini açıklarken, toplumsal yapılarının örgütleniş biçimleri, ortak yaşamın sürdüğü oymakların niteliği, sosyal yasaları, dinsel törenler, toplumsal ortamla din arasında kurulan tinsel ve maddi bağ ve dinin kökeni üzerine bilgi vermiştir. Ayrıca bu rasyonaliteyi sürdürerek din sosyolojisi ve bilgi sosyolojisiyle ilgili belirlemelerde bulunmuştur. $\mathrm{Bu}$ arayış yalnızca sosyolojik düşünceye ve sosyal teoriye yansımakla kalmamış, toplumsal yapıyı ve sorunlarını anlamak için uğraş veren sosyal hizmet disiplininin teorik yönelimi içinde de yer etmiştir. Durkheim'e göre kısaca:

Dinin temel amacı insana maddi evrene ilişkin bir görüş vermek değildir; çünkü, eğer asıl yaptığı iş bu olsaydı, varlığını nasıl olup da sürdürebildiğini anlayamazdı; çünkü maddi evrene ilişkin olarak dinin söyledikleri, bir yanlışlar yumağından başka bir şey değildir. Ama din, her şeyden önce, bireylerin üyesi oldukları toplumu tasarlamalarını sağlayan kavramlar dizgesi ve toplumla aralarında sürdürdükleri karanlık ama içten ilişkiler dizgesidir. Toplum, ancak insanların bilinçlerinde tuttuğu yer ölçüsünde gerçekliğe sahiptir ve bu yeri ona veren bizleriz. Bireyler toplumdan vazgeçemeyecekleri gibi, toplum da bireylerden vazgeçemez (Durkheim, 2010: 313, 474).

Durkheim'in toplumsal olguları kapsayan çalışmaları, yukarıda sözünü ettiğimiz konularla sınırlı değildir. Özellikle farklı disiplinlerin çalışma alanlarında yer etmiş intihar olgusuna ilişkin detaylı bir çalışmanın altına imza attığı bilinmektedir. İntihar konusundaki sosyolojik incelemesi günümüzde önemini korumakla birlikte yol göstericidir. Durkheim intihar çalışmasında, başlıca iki amaç etrafında hareket etmiştir. Bunlar:

1) İnsan olaylarının toplumsal (yani toplu durumunda yaşama zorunluluğundan kaynaklanan) yönleri vardır; toplumsal olguların etkenleri de ancak toplumsal nitelikte etkenler olabilir görünüşü vurgulamak, böylece sosyolojinin bilimler dünyasında meşru varlığgnı kanıtlamak.

2) Kapitalist-sanayi toplum koşullarına girmiş bulunan Batı Avrupa toplumlarında, temel toplumsal işlevlerini yerine getirmesi gerekli kurumların, bu yeni koşullara uyarlanamamış bulunduklarını göstermek. Aile, eğitim, siyasal güç, ekonomi, inanç ve ideoloji gibi kurumlarda ortaya çıkan değişimlerin anlaşılıp açıklanabileceğini ve bilgili olarak belli amaçlara doğru yönlendirilebileceğini vurgulamak. İşte 
Durkheim'in bu her iki amaç için seçtiği inceleme konusu intihar olgusu olmuştur. Neticede bu amaçlar çerçevesinde Intihar'da ortaya konulan görüşler, Durkheim'in sosyolojik yöntem anlayışının verimliliğinin özellikle güçlü bir delilidir (Kızılçelik, 1994: 198; Giddens, 2014: 149).

İntiharı sosyolojik bir olgu halinde sosyal analize tabi tuttuğu için sosyal teorinin bakış açısını zenginleştirmekle kalmamış, intiharın nedenleri ve sonuçları üzerine çalışacak farklı disiplinlerin bir araya gelmesine de olanak açmıştır.

\section{Durkheim'in Sosyolojisinde İntihar Olgusu}

Toplumsal yapının ve toplumun işleyişinin incelenmesi, sosyolojinin kurucularının olduğu kadar çağdaş sosyal kuramcıların da çalışma alanına girer. Sosyolojide farklı bir perspektif geliştiren yapısal işlevselciliğin yükselişi, Durkheim'in yazıları ile çok büyük bir ivme kazanmıştır. Durkheim modern toplumu kendine ait bir gerçekliğe sahip organik bir bütün olarak görür. Bu bütün normal durumunda var olabilmek için bütünü oluşturan parçalar tarafından karşılanan gereksinme veya işlevlere sahiptir. Eğer bazı temel gereksinmeler karşılanmazsa patolojik bir durum ortaya çıkar. Ekonomik işlev modern toplumda karşılanması zorunlu bir gereksinmedir. Ekonomide şiddetli bir dalgalanmanın varlığı, sistemin diğer parçalarını ve sonuçta da bütün sistemi etkileyecektir. Şiddetli bir buhran siyasal sistemi altüst edip, aile sistemini değiştirir ve dinsel yapıda değişmelere neden olabilir. Sistemdeki böyle bir sarsıntı, sistemin kendi kendine çalışması ile yeniden normal durumunu kazanabileceği patolojik bir durum olarak değerlendirilebilir. Çağdaş işlevselciler, normal durumu (normal state) denge (equilibrium) veya dengelenmiş sistem şeklinde adlandırırlarken, patolojik durumu (pathological state) dengesizliği veya toplumsal değişmeyi temsil eden yönüyle kabul ederler (Polama, 1993: 31, 33). Patolojik olan bu dengesizlik durumuna birçok sosyal sorun eşlik eder.

Sosyal teoride toplumun işleyişi incelenirken, toplumsal olgulardan yola çıkılması tartışılmaz bir gerçektir. Din, hukuk, siyaset, eğitim, sosyal refah, ekonomi, aile gibi temel kurumları incelenen toplumsal olgular anlaminda siralayabiliriz. Toplumun işleyişine etki eden ya da ondan etkilenen bu kurumlarla etkileşimde bulunan işsizlik, yaşlılık, yoksulluk, sosyal dışlanma, şiddet, suç, intihar gibi olgular da bu konular arasında yer alır. Elbette yaşadığımız 21. yüzyılda sosyal sorun halini sürdüren 
olgular bunlardan çok çeşitlidir. Göç, mültecilik, engellilik, kadına yönelik şiddet, gençlik sorunları, madde kullanımı, çalışan çocuklar gibi sosyal refah alanlarında yaşanan ve toplumsal koruma kurumunu işlevsel kılan çok sayıda sosyal sorun vardır. $\mathrm{Bu}$ sorunların hepsi de birbirinden etkilenmektedir. Örneğin savaşların neden olduğu bir insan akışkanlığı türü kabul edilen sığınmacı ve mülteci olma durumu, beraberinde birtakım olumsuz ekonomik ve psikososyal süreçlerin yaşanmasını getirmektedir. Uyumsuzluk, ekonomik ve sosyal yoksunluk, yalnızlık ve ötekileştirilme gibi olumsuzluklara maruz kalan bireyler, bazen intihara sürüklenebilmektedirler. Bununla ilgili örnekler çoğaltılabilir. Konumuza dönecek olursak: İntihar olgusunun gerçekleşmesinde genellikle üç etmenin rol oynadığı kabul edilir:

1) İntihar kavramına karşı toplumun grup olarak geliştirmiş olduğu tutum.

2) Kişinin kendi dışından gelen zorlanmalar.

3) $\mathrm{Bu}$ etmenlerin bireyin karakteri ve kişiliğiyle etkileşimi.

İntihar oranının bazı toplumlarda oldukça düşük olmasına karşılık bu olgu, bazı kültürlerde benimsenmekle kalmamış, belirli koşullar ortaya çıktığında girişilmesi zorunlu bir davranış biçimi olarak kabul edilmiştir. Çağdaş toplumlardan Japonya'da intihar olayı bazı özel koşullarda, örneğin bireyi ya da toplumu küçük düşürücü bir duruma tepki olarak ortaya çıktığında, toplumun onayıyla karşılanmaktadır. Bu nedenle İkinci Dünya Savaşı'nın son günlerinde çok sayıda Japon köylüsü, yaklaşan düşman güçlerine tutsak olmamak için intihar etmişlerdir. Farklı bir örnekten yola çıkarsak, benlikleri gelişmemiş özsever insanlar bilerek ya da bilmeden toplumdan, kendi psikolojik, hatta bedensel yaşamından kaçıp kurtulmak amacına yönelik davranışlarda bulunur. Toplumdan uzaklaşmayla başlayan bu davranışlar yaşamdan kopmayla, başka bir deyişle intiharla da noktalanabilir (Geçtan, 1994: 163; Köknel, 1987: 388). Sonuçta intihar olgusunun boyutları zamanla sağlık ve sosyal mesleklerin önemini ortaya çıkarmıştır.

Durkheim Intihar çalışmasında, 26.000 intihar dosyasını tarayarak ulaştığ verilerden yola çıkarak düşüncelerini sistematize etmiştir. Öncelikle makro bir bakış açısıyla karşılaştırma yaparak verileri değerlendirmiştir. Her toplumda bir intihar eğilimi olduğunun altını çizmiştir. Ona göre intiharın etkenleri arasında sosyoloğu 
ilgilendirenler, yalnız toplumun bütününde etkisi olanlardır. İntiharların oranı bu etkenlerin sonucudur. Çalışmasında şu ögeler üzerinde durmuştur: İntihar üzerinde psikolojik hastalık durumları etkili olabilir; yani toplum dışı etkenler; akıl hastalıklarından kaynaklı olarak ele alınabilir; örneğin manyak, melankoli, saplantı, tepisel intiharlar gibi. Bunların dış koşullardan bağımsız oluşuna dikkat çekmiştir. Öte yandan akıl hastalıkları ile intihar arasında bir ilişki kuramamıştır. Alkolizmin etkisinin olmadığını da örneklemiştir. İntihar ile arasında düzenli ve tartışma götürmez bir ilişki bulunan hiçbir ruhsal bozukluk durumu yoktur, sonucuna varmıştır. Bir toplumda intiharların daha çok ya da daha az oluşunun, oradaki ruh hastalarının daha çok ya da daha az oluşuyla anlamlı bir ilişkisinin olmadığını belirtmekle birlikte, intihar oranlarının değişimiyle ırk türleri arasında da bir ilişki kuramamıştır. İntiharın kalıtsal yönünü işleyen kuramların geçersiz olduğunu German, Kelt-Romen, Islav, Ural-Altay türleri arasında örnekleyerek açıklamış ve bir nedensellik bağı kuramamıştır. Yine intiharın yaşlara göre değişmekte olması, herhangi bir organik psişik durumun onun belirleyici nedeni olmayacağını göstermektedir, saptaması toplumsal etkene verdiği değeri ortaya çıkarmıştır (Durkheim, 1992: 34, 63, 88).

Durkheim intihar oranları ile kozmik nedenler arasındaki ilişkiyi de araştırmıştır. $\mathrm{Bu}$ minvalde iklim ve mevsimlik hava sıcaklılarını ele almıştır. Ancak bunun intihara etkisini tam anlamıyla saptayamamıştır. Böylece intiharı toplumsal nedenlere bağlı bir eğilim olarak görmeyi tercih etmiştir. Durkheim intihar tiplerini dört gruba ayırmaktadır. Bencil intihar: dini inançlar ile intiharlar arasındaki ilişkiyi irdelerken, dinin intihara karşı koruyucu bir etkisi olabilir, tezini savunmaktadır. O’na göre, meslek sahipleri, aile, evlilik, savaşlar, toplumsal bunalımlar gibi sosyal faktörlerle intihar arasında bir etkileşim olabilir. Dinsel topluluk, aile kurumu, siyasal toplumun bütünleşme ölçüsüyle ters orantılı olarak intihar değişmektedir. Şöyle bir çıkarım yapılabilir, bireyin üyesi olduğu kümeler ne kadar zayıflarsa, onlara bağımlılığı o ölçüde azalır ve sonuç olarak da daha çok yalnızca kendi kendisine dayanır ve kendi kişisel çıkarları üzerine kurulu davranış kurallarından başka kural tanımaz. Bu durumda, eğer bireysel ben'in toplumsal ben karşısında ve onun aleyhinde aşırı ölçüde vurgulanmasına bencillik demek uygun düşerse, aşırı bir bireycilikten kaynaklanan özel intihar türüne bencil intihar denebilir. Burada küme ya da topluluğun etkisini görüyoruz. Toplumsal bir varlık olan birey, çevresini oluşturan toplum içinde bir bütün olmakla 
birlikte sosyal rollerini yerine getirir. Bu durum bireyin benlik bütünlüğüne ve sosyal uyumuna olumlu yansır. Bunun tersi durumlar bireyi toplumsal anlamda yalnızlaştırır, toplumun dişına sürükler. Sosyal uyumsuzluk bireyi bencil intiharlara sürükleyebilir. Durkheim'de toplum önemlidir; bireyin toplumsallığ1 ve toplumun bireye yön veren gücüne atıf yapılır. Aşırı bireyleşme intihara götürdüğü gibi, yeterince bireyleşememe de aynı sonuçları doğurur. Elcil intihar: İnsan toplumdan koptuğunda kendini kolaylıkla öldürdüğü gibi onunla aşırı biçimde bütünleştiğinde de kendini öldürebilmektedir. Burada ortaya şu çıkmaktadır, toplumsal amaç yerine göre bireyi intiharı gerçekleştirmeye itmektedir. Bencilliğin aksine toplumu aşırı içselleştirme söz konusudur. İntihar yerine göre yiğitlik ve saygınlık göstergesi olarak kabul edilebilmektedir. Bazı dinlerde; Budizm, Hinduizm, Jainist dini, Japonya örneklerinden yola çıkarak abartılmış erdem ve sapmış biçimiyle buna rastlanmaktadır. Kuralsızlık intiharındaysa; ekonomik bunalımların intihar eğilimi üzerinde ağırlaştırıcı bir etkide bulunduğu bilinmektedir. Durkheim'in değerlendirmesinde yabancılaşmayla yakından ilgili kuralsızlığı doğru okumak gerekir. Denebilir ki, çağdaş toplumlardaki kuralsızlık, intiharların düzenli ve özel bir etkeni durumundadır; yıllık intihar tutarını besleyen kaynaklardan birisi de budur. Durkheim, intihar olgusuyla ilgili yaptığı çalışmasında çok az değinmekle yetindiği bir intihar türü olarak fatalist/kaderci intiharı da dile getirir. Katı sınırlar için duygularını ve düşüncelerini bastırarak, aşırıya kaçmış bir sosyal ve bireysel kontrolün bu intihara neden olduğu ileri sürülebilir. Özetle bencil intihar, insanların artık yaşam için bir gerekçe görememelerinden kaynaklanıyor; elcil intihar, insanların yaşamın gerekçesini yaşamın dışında görmelerinden ileri geliyor; üçüncü tür intihar ise insanların etkinliklerindeki düzenin bozulmasından ve onların bundan acı duymalarından kaynaklanıyor. Kökeni nedeniyle bu sonuncu türe kuralsızlık intiharı adının verildiğini biliyoruz. Kaderci intihar ise sosyolojik bir anlam ifade etmediği için tam anlamiyla bir değerlendirmede bulunulmuyor (Durkheim, 1992: 209, 210, 219, 245, 263).

Durkheim, Intihar incelemesinde ayrıca topluma bağlılık oranı fazla olan kişilerde intihar olaylarının, grup özdeşleşmesi yapamamış kişilere oranla daha seyrek görüldüğünü, intihar oranının evlenememiş ya da boşanmış kişilerde evli olanlardan, dindar olmayanlarda dinine bağlı kişilerden daha yüksek olduğunu açıklamıştır. Aynı incelemede, ekonomik bunalım ya da savaş yenilgisi sonrası gibi toplum değerlerinin 
bozulduğu dönemlerde de intihar olaylarının arttığını öne sürmüştür. Durkheim bu bulgulardan, kişinin özdeşleştiği toplum grubuyla arasındaki bağlarının zayıflamasının ve grubuna yabancılaşmanın (anomie) intihar olaylarında başlıca etmen olduğu sonucuna varmıştır. Başka bir açıdan Durkheim'e göre toplumdaki intihar oranı, bir sosyal grup veya toplumun anomi derecesinin bir işaretidir. Durkheim, sanayi ve ticaret toplumlarında çok yüksek oranda intihar tespit edince bu çeşit toplumların ileri derecede anomik olacaklarını kabul etmiştir (Geçtan, 1994: 164; Dönmezer, 1994: 237). Kuşkusuz toplumdan topluma değişik oranlarda da olsa bencilliği, elcilliği ve bir ölçüde kuralsılığı birleştirmeyen hiçbir ahlaki düşünce yoktur. Çünkü toplumsal yaşam aynı zamanda hem bireyin belli bir kişiliğe sahip olduğunu, hem toplum gerektiriyorsa ondan vazgeçmeye hazır olduğunu, hem de bir ölçüde ilerleme düşüncelerine açik olduğunu anlatır. Bundan dolayı, insanı üç ayrı hatta çelişik yöne yönelten bu üç düşünce akımının bir arada bulunmadığı hiçbir toplum yoktur (Durkheim, 1992: 331). Başka bir açıdan, birey, toplumla pozitif bir ilişki kurduğunda onun varlığı daha anlamlı hale gelir ve o içinde yaşadığı topluma faydalı olur. Fakat toplumla bağını koparmış bir birey, sadece kendisine yoğunlaştığı için bu durum o kişide yalnızlaşma sorununu ortaya çıkarır. Sosyolojik teoriler, bu noktada kişinin niçin kendisini toplumdan yalıttığını veya toplumun bireye hangi sebeplerden ötürü ilgisiz kaldığını araştırarak kişiyi intihara götüren saikler üzerinde durur. Sosyolojik intihar teorilerinin araştırmalar neticesinde ortaya koyduğu fotoğraf, intihar olgusunun anlaşılmasında önemli rol oynar ve bireylerin sağlıklı bir ruh hali ile toplumda huzurlu bir şekilde yaşamasına yardımcı olur (Sümer, 2015: 8, 9).

Durhkheim'in Intihar çalışmasıyla ilgili yapılan eleştirilere de bakmakta yarar var. Eleştirilerin genelini yansitacak şekilde Aron şu değerlendirmede bulunur: Durkheim'in inandırıcı bir kanıtlama yapmadan çağdaş toplumda intihar oranının artmasının patolojik olduğu ya da var olan intihar oranının çağdaş toplumdaki bazı patolojik özellikleri ortaya koyduğu yargısına varır. Çağdaş toplum, bilindiği gibi, toplumsal farklılaşma, organik dayanışma, nüfus yoğunluğu, iletişim sıklığı ve yaşam için mücadele ile belirginleşir. Çağdaş toplumun özüyle bağıntılı bu olguların anormal olarak değerlendirilmemesi gerekir (Aron, 1994: 239, 242). 
Sonuçta farklı yaklaşımlar 1şı̆̆ında zamanla intihar konusunda makro-mezzomikro düzeylerde incelemelerin sayısının arttığını, intiharın nedenleri, intiharı önleme ve mücadelenin boyutlarıyla ilgili çalışmalara ağırlık verildiğini görmekteyiz.

\section{Sosyal Hizmet Disiplini ve Mesleği Açısından İntihar ve İntiharla Mücadele}

Ölen kişi tarafından ölümle sonuçlanacağı bilinerek yapılan olumlu ya da olumsuz bir edimin doğrudan ya da dolaylı sonucunda gerçekleşen her ölüm olayı intihar olarak tanımlanmaktadır (Durkheim, 1992: 25). İntiharın psikodinamiğinde bireysel patolojilerin yanında toplumsal nedenlerin yer aldığı bilinmektedir. Bireylerin intihara sürüklenmeleriyle ilişkili eğitim, işsizlik, yaş, cinsiyet, hastalık, göç, meslek ve yerleşim yerini veren istatistikler dönem dönem yayınlanmaktadır. Sosyal hizmet mesleği de temel yöntemlerinden biri kabul edilen sosyal hizmet araştırması yoluyla intihar gibi bir sosyal sorunla ilgili mesleki uygulamalara 1şı tutacak şekilde nicel ve nitel araştırmalar gerçekleştirmektedir. Ancak yapılan araştırmalar belli bir örnekleme dayanmakla birlikte ulusal anlamda temel veriler Türkiye İstatistik Kurumu tarafindan derlenip, paylaşılmaktadır. Örneğin 2014 tarihi itibariyle Türkiye İstatistik Kurumu verilerine göre, 3169 ölümle sonuçlanan intihar olayı meydana gelmiştir. İntiharlar en fazla yaşlı grubunda görülürken, verilerde en fazla intihar olayının evli kişilerde rastlandığı belirtilmiştir. Kurumun 2015 yılıyla ilgili verileri ise şu şekildedir: Ölümle sonuçlanan intihar sayısı 2014 yılında 3169 iken 2015 yılında \%1,3 artarak 3211 kişi olmuştur. İntihar edenlerin \%72,7'sini erkekler, \%27,3'ünü kadınlar oluşturmuştur. İntihar eden kişiler yaş grubuna göre incelendiğinde, 2015 yılında intihar edenlerin \%34,3'ünü 15-29 yaş grubundakiler oluşturmuştur. İntihar eden kişiler cinsiyete göre incelendiğinde, intihar eden kadınlarda en yüksek oran \%18 ile 15-19 yaş grubunda bulunurken, erkeklerde bu oran en yüksek \%12,8 ile 20-24 yaş grubundadır. İntihar eden erkeklerin \%33,3'ünü, kadınların ise \%46'sını 30 yaşından küçükler oluşturmuştur. İntihar eden kişilerin 2014 y1lında \%22,2'si ilkokul mezunu iken 2015 yılında bu oran \%23,7 düzeyine çıkmıştır. İlkokul mezunlarını \%21,4 ile ilköğretim, $\% 20,9$ ile lise ve dengi okul, \%11,7 ile yüksek öğretim mezunları izlemiştir. İntihar eden kişiler medeni duruma göre incelendiğinde, 2015 yılında intihar edenlerin \%50,5' 'ini evli, \%37,7'sini hiç evlenmemiş, \%7,2'sini boşanmış, \%4,6'sını ise eşi ölmüş bireyler meydana getirmiştir. Cinsiyete göre medeni durum incelendiğinde, 2015 y1lında 
intihar eden erkeklerin \%54'ünün evli, \%36,4'ünün hiç evlenmemiş, intihar eden kadınların ise \%41,1'inin evli, \%41'inin hiç evlenmemiş olduğu belirlenmiştir. 20142016 verileri dikkate alındığında toplamda intihar eden 9479 kişi içinde 15 yaşından küçük çocukların sayısının 284 olması ise çarpıcı bir gerçekliktir (İntihar İstatistikleri Türkiye İstatistik Kurumu, 2014, 2016). Türkiye'deki verilere geçmiş yıllara dönük boylamsal olarak bakıldığında, yılda ortalama ölümle sonuçlanan intihar olgularının sayı olarak 3000 ile 4000 arasında yoğunlaştığını söylemek mümkündür. Öte yandan toplumsal cinsiyet açısından ele alındığındaysa, 2002-2015 yılları arasındaki intihar sayılarından yola çıkılarak yapılan analizlerde elde edilen sonuçlardan bazıları şu şekildedir: İntihar eden kişilerin 14 yılın ortalaması alındığında erkekler için 1957, 64 kadınlar için ise 919, 57 olarak görülmüştür. Türkiye'de yaşayan erkekler kadınlara göre daha fazla intihar etmektedir. Kadın ve erkeklerin intihar oranları sirasıyla \%32, \%68'dir. İntihar rakamları 2002 yılından 2015 yılına doğru kadınlarda dalgalı olarak artmış ve azalmıştır (Özcan, Şenkaya vd. 2018: 29).

Olguyla ilgi psikolojide bireysel trajediler ve kişilik yapısına bağlı özellikler ağırlıklı olarak değerlendirilirken, sosyolojide daha çok toplumsal etmenler ön plana çıkarılmıştır. Bütünsel yaklaşıldığında bireysel ve toplumsal etmenlerin ayrı ayrı rollerinin değerlendirilmesinin yapısal bir zorunluluk olduğunu kabul etmek gerekir. Sosyal hizmet disiplini iki değerlendirme biçiminden yararlanma yolunu seçmenin yanı sıra intiharın nedenleri, sonuçları ve intihara karşı mücadele önerileri üzerinde yoğunlaşmaktadır. Sosyal hizmet felsefesi açısından, intiharın yaygınlığı insanın ve toplumun gelişimi önünde bir engeldir. Sosyal hizmet mesleği, amaçları arasında yer alan; bireyin onur ve haysiyetine odaklandığından intiharı insani birikime dönük bir tehdit görür. Birey toplum etkileşimini, karşılıklı sorumluluk yönüyle kabul eder. Bireyin gelişimi için toplumun sorumluluğunu savunur. Bireyin gelişimine katk1 sağlayan toplum aynı zamanda demokratik ideallere duyulan güveni ve inancı pekiştirir. Demokratik toplum anlayışı ekolojik yaklaşımdan bakıldığında, sosyal sorun yaşayan bireylere dönük koruyucu-önleyici yaşanabilir-sürdürülebilir fiziksel ve sosyal bir çevrenin olanaklarını genişletir. $\mathrm{Bu}$ yönüyle ihtiyaç içindeki bireyin intiharla deneyeceği, yaşamını sonlandırma hareketlerinin ortadan kaybolmasa bile aşağı seviyelere inmesine yardımcı olur. Olguya ilişkin bireyle, grupla ve toplulukla yapacağı çalışmalarda birey ve toplum refahını temel alır. 
Sosyal hizmet mesleği intihar gibi bir sosyal sorun alanında işlevsel olurken, bütünsel bakış açısını göz ardı etmez. Bir veya bir dizi sorunun yansıması olan intihar olgusunu psikososyal ve ekonomik koşulları içinde değerlendirir. Bu nedenle farklı disiplinlerden yararlanma yolunu da seçer. Örneğin sosyal psikoloji yönünden bakıldığında Durkheim'in intihar olaylarını incelemesine salt sosyolojik yaklaşımla eğildiği tartışma konusu yapılır: Durkheim intiharı sosyal bir olay olarak ele aldığı çalışmasında sosyal yapı çöküntüsü ile intihar (sosyal olay oranı: sosyal etki/bağımsız değişken-sosyal tepki/bağımlı değişken) arasında bir nedensel ilişki kurmuştur. Toplumsal çöküntü devrelerinde intihar olaylarının sayısının arttığını gösteren bu modelde, sosyal yapı çöküntüsü, bağımsız değişken (sebep); intihar (sosyal olay) da, bağımlı değişken (sonuç) olarak nitelendirilebilir. Burada bireysel düzeye hiç inilmediği, sanki intihar eden insanın bireysel özelliklerinin hiç önemi yokmuş gibi düşünülerek tamamen sosyal olaylar düzeyinde bir çözümleme yapıldı̆̆ı açıktır. Nitekim Durkheim, bir sosyal olayın nedeni ancak başka bir sosyal olaydır diyerek salt bu sosyolojik gerekçeyi açıklamıştır. Bu ele alış doğrudan sosyal düzeyde olduğu için bir sosyal olayın artışını ya da azalışını açıklayabilmekte, sosyal düzeydeki soruları cevaplayabilmektedir. Ancak bireysel düzey bu çözümlemede kullanılmadığı için, bu ele alış, bireylere yönelik soruları doğal olarak cevaplayamamaktadır (Kağıtçıbaşı, 1988: 5). Kuşkusuz Durkheim'in intihar incelemesinde son derece bireysel bir olgu gibi görünen intiharın nedenlerinin bireyin toplumla ilişkisindeki düzensizlikler ve dalgalanmalardan kaynaklandığını savunduğunu görmekteyiz. Kuramının toplumsal bütünleşme ve toplumsal düzenleme olmak üzere iki ana odağı vardır. Toplumsal bütünleşme ve düzenleme düzeyleri yüksek veya düşük olabilir. İki toplumsal olgunun düzeyine göre dört farklı intihar tipi üzerinde durduğunu anımsayalım. Durkheim'in sosyolojik kuramı intiharların nedenlerini toplumsal olaylara veya toplumsal birtakım oluşumlara bağlamaktadır. Bireyin psikolojik yapısındaki işlevsel düzensizliklere değinmemektedir. İntihar gibi çok yönlü bir davranışı anlama ve açıklamada böyle bir yaklaşım ne kadar etkin olabilir? Sorusunun karşılığında ise şu yanıtı verebiliriz: Her şeye rağmen Durkheim'in kuramı intihar davranışının toplumdan topluma değişen görülme sıklığını açıklamada çok başarılı bir kuramsal yaklaşımdır. Ancak bu başarısına dikkat çekilirken, yaklaşımının intiharları bireysel düzeyde açıklamaya yetmediği veya yetersiz kalabildiği ileri sürülmektedir. Bu anlamda dış veya toplumsal olayların intihar 
davranışını doğurduğunu varsaysak bile aynı dış etmenleri yaşayan bireylerden bazıları intihar davranışı sergilerken bazı kimselerin dış zorlamalara rağmen kişisel uyumda zorlanmadıkları ve intihar davranışı sergilemedikleri bilinen gerçekler arasındadır. Bu nedenle göç, işsizlik, meslek, psikososyal ve çevresel faktörlerin yanında intihar davranışı ve intihar sonucu ölüm cinsiyete, yaşa, ırka ve medeni duruma göre farklılıklar içeren çok sayıda risk faktörüyle ilişkilidir (Eskin, 2003: 124, 125, Engstrom, 2006: 194, 251).

Unutulmamalıdır ki Durkheim, her şeyden önce bir sosyologdu. Bir bilim olarak sosyolojinin ve ileri sürdüğü yöntemin alanını genişletiyordu. İntihar çalışmasında bireysel etkenleri önemsiyordu ancak onların bir yasa haline gelecek kadar belirleyici olmadığını söylüyordu. Örneğin bireysel intihar olayları psikolojik güdülenmelerle açıklanabilir; ancak bir toplumda belirli bir dönemde işlenen intiharlar diğer bir devrede işlenen intiharlarla karşılaştırılabilince artık bir sosyal olay halini alır. Bundan böyle iki devre arasında işlenen intiharlar bakımından var olan sabit oranı psikolojik güdülenmelerle açıklamak mümkün olamaz; burada artık bir sosyal faktör aramak gerekir ve bu sosyal etmen, bireyin üyesi bulunduğu gruba duyduğu bağlllık türünden ibarettir (Dönmezer, 1994: 36). Yıllar sonra sosyal psikoloji disiplininin gelişmesiyle toplumsal olguları ele alışta ara değişkenlerin önemi değerlendirilmiştir. Kısmen eleştirilse dahi Durkheim'in yaklaşımı sosyal teoriyi zenginleştirmiştir.

Görüyoruz ki Durkheim, bir sosyolog kimliğiyle herhangi bir bireyin niçin intihar ettiğiyle ilgilenmedi. Bu, psikologlara bırakılacaktı. Bunun yerine Durkheim, intihar oranlarındaki farklılıkları açıklamaya ilgi duydu; yani niçin bir grubun diğerinden daha yüksek bir intihar oranının olduğuna dikkat çekti. Psikolojik veya biyolojik etmenler, bir grup içinde belirli bir bireyin niçin intihar ettiğini açıklayabilir. Ne var ki Durkheim, niçin bir grubun diğerinden daha yüksek intihar oranının olduğunu sadece toplumsal olguların açıklayabileceğini varsaydı (Ritzer, Stepnisky, 2014: 92). Elbette her şeyden önce bu konuda net bir tutuma sahipti. Yöntem kitabında bunu doğrulamaktadır. Aydınlatıcı olması açısından şu tezin üzerinde durmak gerekir: Sosyolog, ne zaman, herhangi bir toplumsal olgular sınıfını araştırmaya girişirse, onları, bireysel tezahürlerinden ayrılmış olarak ortaya çıktıkları bir yandan incelemeye çalışmalıdır. Bir toplumsal olgunun belirleyici nedeni, bireysel bilinç halleri arasında 
değil, önceki toplumsal olgular arasında aranmalıdır (Durkheim, 1985: 74-125). Bu nedenle artık günümüzde hastalıklar, istismar, cinsel kimlik karmaşası, madde kullanımı, hane içi şiddet, yoksulluk, iç savaşlar, mültecilik ve göçmenlik, evsizlik gibi faktörlerin intihar girişimine ya da intihar sonucu ölüme etkileriyle ilgili psikososyal araştırmalara da ağırlık verilmektedir.

İntiharın sosyal analizinden yola çıktığımızda, intihara neden olan etkenler ve intiharın sonuçlarıyla mücadelede sosyal hizmetin işlevinin ne kadar önemsenmesi gerektiğini kabul etmemiz gerekir. Bireyin yok oluşu, aslında yalnızca bireysel patolojilere indirgenemez, birey etik varlığıyla ancak toplumda var olabilir. Sosyal hizmetlerin kurumsal bağlamda yaygın olmadığı toplumlarda sosyal destek sistemleri işlevsel değildir. Sosyal hizmet disiplininin ve mesleğinin kurumsallaştığı, bireylerin sosyal-ekonomik ve psiko-kültürel gereksinimlerinin yeterince giderildiği toplumlarda intiharın hem insanlığa maliyeti hem de olabilme sıklığı düşer. İnsan onur ve haysiyetinin sosyal hizmetin temel değerleri olduğu gözetildiğinde her iki değerin bireytoplum etkileşiminde ne değin dikkate alınması gerektiği ortaya çıkmaktadır. Eklersek, sosyal hizmet mesleği ve sosyal hizmet disiplini insan hakları felsefesini içerikleştirmiş kimliğiyle, sosyal adalet ve sosyal planlama, toplumsal gelişme, sosyal refah ve sosyal devlet gibi gerçekliklerle bir bütün halindedir. Bunların, toplumsal yapı düzenlenirken referans alınması sağlıklı bir toplum yapısını var kılar (Şeker, 2013: 113).

İntihara sürüklenen bireylerin toplumsal koşullardan kaynaklı açmazları, sosyal hizmetlerin bir hak olarak gözetildiği, adaletli, katılımc1, sosyal ve ekonomik destek olanakları kısıtlı olmayan toplumlarda rahatlıkla üstesinden gelinecek sorunlardır. Çünkü bu tip sağlıklı toplumlarda birey kendisini, karşılaştığı sorunları çözen, değerli ve onurlu bir varlık olarak görür. Dahası intiharla mücadelede geleneksel toplumun dayanışmacı ruhuyla, çağdaş toplumun birey özgürlüğüne saygı anlayışını toplum temelli bir anlayışla bütünleştirebilirsek, toplumsal gelişme adına bir çıkış kapısı aralayabiliriz. Sosyal hizmetin; sosyal ilişkilerin geliştirilmesi, toplumsal değişme ve gelişme, demokratik katılım, toplumsal sorumluluk, toplumsal cinsiyet eşitliği, sosyal adalet ve birey özgürlüğüne saygı gibi değerlerinin siyasi erki elinde bulunduranlar tarafindan içselleştirilmesi burada daha çok önem arz ediyor. 


\section{Sonuç}

İntihar olaylarının tarihçesini inceleyen Dublin, bu konuya eski çağlarda büyük ilgi duyulmuş olduğunu, ancak 19. yüzyılın sonlarına kadar bilimsel bir biçimde ele alınmamış olduğunu saptamıştır. İlk kez Durkheim 1887'de yayımlamış olduğu 'Le Suicide': Intihar adlı ünlü monografında, bu sorunu istatistiki verilerle ve toplumsal yönleriyle geniş ve ayrıntılı bir biçimde ele almıştır. Çalışma boyunca dikkat çektiğimiz Durkheim'in intihar olgusuyla ilgili vardığı bulgular, bazı yönleriyle eleştirilse dahi sonraki yıllarda yapılan birçok araştırmada doğrulanmıştır (Geçtan, 1994: 164). Durkheim intihar araştırmasını, intiharı önlemek için hangi reformların yapılabileceğini inceleyerek sonuçlandırmıştır. Diğer yandan intiharı önlemeyi amaçlayan çoğu çaba, intiharı bireysel bir sorun olarak gördüğü için başarısız olmuştur. Sosyal reformcu yönüyle ileri çıkan Durkheim'e göre bireyleri intihar etmemeye ikna etmeyi amaçlayan doğrudan çabalar, anlamsızdır, çünkü intiharın gerçek nedenleri toplumun içindedir. $\mathrm{Bu}$ nedenle toplumsal önlemlerin değerinin altını çizer. Ayrıca Durkheim, belirli bir oranda intiharın normal olduğunu kabul ederken modern toplumda hem bencil hem de anomik intiharların patolojik bir artış gösterdiğini anlatır. Burada Durkheim görüşünün kökenini İşbölümü'nde ayrıntılı olarak açıklamaktadır. Bu eserde Durkheim, modern kültürün anomisinin dayanışmadan çok yalıtılmaya yol açan anormal biçimdeki iş bölümünden kaynaklandığını ileri sürmüştür. Bu durumda, gerekli olan şey, intiharları gereğinden fazla artırmaksızın modernliğin sosyal-ekonomik yararlarını koruma biçimidir. Toplumsal koşullar refah açısından dengelendiğinde, intiharı tetikleyen çeşitli toplumsal akımlar da etkili olmaktan çıkabilir. Durkheim, toplumda bu akımların, dengesiz olduğuna inanır. Denebilir ki toplumsal düzenlemeler ve toplumsal bütünleşme adına yapılan çalışmaların azlığının ortaya çıkardığı durumlar, anomik ve bencil intiharların oransal açıdan artmasına yol açmaktadır (Ritzer, Stepnisky, 2014: 97, 98). Durkheim, mutluluğun çağdaş toplumun ilerlemesiyle artmadığının en iyi kanıtının intiharların sıklığı olduğunu savunurken de ilerlemenin toplumsal adaletle birlikte ele alınmasından yana bir bakış açısına sahiptir. Bu nedenle intiharların çağdaş toplumlarda geçmiş toplumlardan daha fazla olduğunu temellendirirken, toplumsal koşulların sorgulanması gerektiği konusunda nettir. Örneğin günümüz kültürünün insanı cezbedemez duruma geldiğinde, Durkheim'in ümitsizlikten doğan intiharlar olarak anlamlandırdığı türden intiharların artması, sosyolojik açıdan toplumsal koşullara verdiği önemle ele 
alındığında ancak rasyonel bir çözümleme yapılmış olur (Aron, 1994: 231; Bauman, 2012: 15).

Durkheim meslek gruplarını ön plana alarak, toplumsal bütünleştirmeyi kolaylaştıracak ve sağlayacak kurumların intiharla başa çıkmada etkili olacağı sonucuna gitmektedir. Destekleyici şekilde sosyolojik düşüncenin başlıca özelliklerinden biriyse, her özel sorunu tüm toplumsal içeriği içinde ele alarak, tüm toplumsal hayatı etkileyecek alternatif sosyal politikaların tümünü hesaba katmasıdır. Buna yön verecek şekilde koşullarla intihar oranındaki toplumsal bir olgu olan değişimler arasındaki değişkenleri ortaya koymak sosyoloğun görevi biçiminde belirginleşmektedir (Bottomore, 2000: 360; Aron, 1994: 234). İş bölümü aracılığıyladır ki birey, topluma duyduğu bağlılık durumunun bilincine varır; onu durduran ve sınırlandıran güçler toplumdan gelmektedir. Kısacası, iş bölümü toplumsal dayanışmanın önde gelen kaynağı olduğundan, aynı zamanda ahlak düzeninin de temeli olmaktadır. Bugün bizim birinci ödevimiz, kendimize bir ahlak oluşturmaktır. Yapılacaklar arasında birtakım sosyal reform uğraşıları olsa bile; yani ailenin güçlendirilmesi, meslek birlikleri, kadının toplumsal yaşamdaki statüsünün artırılması gibi toplumsal düzenlemelerin yanında genel anlamda O’na göre konu doğrudan doğruya toplumsal yapıya ilişkin önlemleri gerektirir (Durkheim, 1992: 109; 2014: 456, 465). Özünde Durkheim, devletin yönetimi altında işsizlik, hastalık ve yaşlılık gibi refah şemaları geliştirecek dayanışmacı bir programa sıcak bakar. Fakat bunların egemen konumlarını sürdürmelerine izin verilmemesi ve sınai düzenin sistematik ahlaki bir temelde düzenlenmesi çabasıyla birleştirilmeleri gereğini de 1srarla vurgular (Giddens, 2014: 311-312).

Doğdukları dünyada insanlar neden yaşamlarına son vermeye karar verir? Yaşam dayanılmaz, 1stıraplı, umutsuz ya da gereksiz olduğu için mi? Ya da umutlarını ve beklentilerini gerçekleştiremedikleri için mi? Belki de kötü giden bir yaşamın yanında olumsuz ekonomik-toplumsal koşullarla baş edemediklerinden... Hem bireysel hem de toplumsal nedenlerden hareket edildiğinde, intiharın gerekçeleri arasında birçok öge sıralanabilir. Neredeyse hayatın her döneminde meydana gelen intihar, bireyi ve toplumu ilgilendirdiğinden güncelliğini kaybetmeyen ve üzerinde araştırmalar yapılan bir olgudur (Zastrow, Ashman, 2016: 482). 21. yüzyılda karşı karşıya bulunduğumuz sosyal sorunların yoğunluğu, yaşama biçimimizde ve peşinden koştuğumuz amaçlarda 
temelden yanlış olan bir şey mi var? sorusunu akla getirmektedir. Şiddet, iç savaşlar, intihar, alkolizm, ayrımcılık, madde kullanımı gibi sorunlar çağdaş uygarlığın insanının derinlerinde yatan gereksinimleri karşılamaya yetmediğini gösteren kanıtlar mıdır? Sağlıklı toplum ve sağlıklı yaşam; insanı yaşam koşullarına bağlayan güvensiz olmayan, insani boyutlarıyla demokratik, özgür ve insan gereksinimlerinin giderildiği bir insancil toplum modelinin sosyal adaletten geçtiğinin farkındadır (Fromm, 1996: 21). Sosyal refah bağlamında sosyal hizmet mesleği de sosyal adaletin geliştiği, gelir dağılımının bozuk olmadığı, sağlıklı bir toplumu amaçlamaktadır.

Sosyal hizmet uygulamasına yön veren amaçların sosyal reform düzenlemelerine katkısını kavramsallaştırdığımızda şu şekilde bir çerçeve çizebiliriz: Sosyal hizmet uygulaması, bireylere ve gruplara, kendileri ile çevreleri arasındaki dengesizlikten doğan sorunların belirlenmesi, çözülmesi ya da etkisiz hale getirilmesi için yardım eder. Dengesizliğin meydana gelmesini önlemek için bireyler ya da gruplarla çevreleri arasındaki potansiyel dengesizlik alanlarını belirler. Tedavi edici ve önleyici önlemlere ek olarak, bireylerin, grupların ve toplumların en yüksek gelişme güçlerini arar, belirler ve onları güçlendirmeyi hedefler. Kısaca, insanların öteki insanlarla ve doğa ile olan ilişkilerini, var olan çelişkileri ortadan kaldıracak biçimde düzenlemelerine yardım etmeyi amaçlar (Kongar, 1972: 21-26). Bu amaçlardan yola çıkarak bakıldığında, 15-35 yaş arası gençlerin ölüm nedenleri arasında ilk üç sırada yer bulan intiharın, aile ve toplum üzerindeki psikolojik, sosyal, ekonomik etkisini ölçtüğümüzde, diyebiliriz ki hem toplumsal hem de bireysel açıdan alınacak toplumsal koruma önlemlerinin bu sorunla mücadelede olumlu yansımaları olacaktır (Küpçük, Büyükkaya vd. 2004: 7). Bu doğrultuda intihar olgusuna kaynaklık eden faktörler analiz edildiğinde, toplum düzeyinde sosyal hizmet mesleğinin uygulaması çeşitli boyutlarda olmaktadır. Örneğin gençlerin okul yaşamlarında okul devamsızlığı, akademik başarı kaygısı, okul ortamına uyumsuzluk, sorunlu öğrenci konumunda görülme, okul yöneticilerinin tutumundan rahatsızlık duyma gibi çeşitli sorunlar yaşayanlar için okul sosyal hizmeti anlayışıyla çalışmalar yapılabilmektedir. Yine sosyal hizmet, intihar girişiminde bulunanlar için gereksinim duyduğu alanlarda; ruh sağlı̆̆ ve sosyal hizmet sunan kuruluşlarda, yerel yönetimlerin ilgili birimlerinde, sosyal yardımlaşma ve dayanışma alanında çalışmalar yapabilir, bu tür toplumsal kaynakların artmasında rol üstlenebilir. Ayrıca bireylerin 
kolayca ulaşabilecekleri yardım birimlerinin kurulmasına çaba sarf edebilir (Alptekin, 2008: 142).

Sosyal hizmet uygulamasının, aslında sosyal reform düşüncesiyle toplumsal düzenlemelerin önemini gözetmiş bulunan Durkheim'in yaklaşımını destekleyen bir niteliği burada öne çıkmaktadır. Bu noktada yalnızca intihara sürüklenen insanlara yönelik tedavi amaçlı bakış açısının, bir sosyal sorun olarak kabul edilen bu olguyla mücadelede verimli sonuçlar doğuracağı yanılgısına kapılmadan bunun bir halk sağlığ sorunu olduğunu belirtmek gerekir. Bir halk sağlığı sorunu olduğu için de önlenebilir bir durumdur. Örneğin hastane bakım sistemlerinde kurulu krize müdahale merkezlerinin işlevlerinin sınırlı olduğu düşünülecek olursa, toplum temelli koruyucuönleyici çalışmaların önemi kabul edilmelidir. Sosyal politika uygulamalarının topluma yaygınlaştırılması, ekonomik sorunlar, işsizlik, yoksulluk gibi yapısal sorunların toplumsal işleyişi sağlıklı hale getirilecek şekilde çözümlenmesi gerekmektedir. $\mathrm{Bu}$ süreçte insan haklarının korunması temelinde hareket eden sosyal hizmet mesleğinin nihai hedefi ise toplumdaki tüm bireyler açısından sosyal refahı arttırmak ve sosyal adaleti sağlamaktır (Çoban, 2017: 159, 170).

Özetle felsefesindeki insancıl öz, değer, amaç ve uygulama diyalektiği açısından bakıldığında sosyal hizmet, bu insanlık sorunuyla da ilgilenmektedir. Sosyal hizmet mesleğine bu alanda sorun çözücü niteliğiyle önemli rol ve bu rollerin işlevlerini yerine getirme sorumluluğu düşmektedir. Sosyal destek kaynaklarına erişim, sosyal refah kuruluşlarının niteliği ve bunların kullanılabilirliğini içine alan, sosyal hizmetlerin yeterli olduğu sosyal sistemler sayesinde bireyi ve toplumu etkileyen sosyal sorunlarla etkin mücadele edilebilir. İntihar gibi sosyal sorunlara dönük çalışmalarda, sosyal hizmet mesleğinin müdahale yetkisi, bireyi ve topluluğu güçlendirici, sistemi insancıllaştırıcı bir meslek olmasından ileri gelmektedir. Meslek, sosyal sistem içerisinde bireyin yaşam niteliğini yükseltmeyi, sosyal çalışmaların olmazsa olmazları arasına yerleştirdiği ölçüde, toplumsal gelişmeyi ve toplumun iyilik halini gerçekleştirmeye katkı vermiş olur. Bireyden topluma uzanan geniş bir alanda intihar gibi bir sosyal sorunla mücadelede başarıya; hiç kuşkusuz klinik odaklı çalışmaların yanında koruyucu önleyici ruh sağlı̆̆ hizmetlerinin geliştirilmesinin, toplum ruh sağlı̆̆ merkezlerinin artırılmasının, genç işsizliğinin önlenmesinin, cinsiyet ayrımcılı̆̆ının 
önüne geçilmesinin, okul sosyal hizmeti sisteminin ivedilikle geliştirilmesinin yanında sosyal refahın geliştiği, insanların yaşam niteliğinin yukarı olduğu, toplumsal değer ve gelecek umudunun korunduğu bir toplumsal yapının inşasının çok büyük oranda katkısı olacaktır.

\section{Kaynakça}

ALPTEKİN, Kamil (2008). Sosyal Hizmet Bakış Açısından Genç Yetişkinlerde Intihar Girişimlerinin İncelenmesi: Bir Model Önerisi, (Yayımlanmamış Doktora Tezi) Hacettepe Üniversitesi, Sosyal Bilimler Enstitüsü, Ankara.

ARON, Raymond (1994). Sosyolojik Düşüncenin Evreleri, çev. Korkmaz Alemdar, İstanbul: Bilgi Yayınları.

BAUMAN, Zygmunt (2012). Ölümlülük, Ölümsüzlük ve Diğer Hayat Stratejileri, çev. Nurgül Demirdöven, İstanbul: Ayrıntı Yayınları.

BOTTOMORE, Burton Thomas (2000). Toplumbilim, çev. Ünsal Oskay, İstanbul: Der Yayınları.

ÇOBAN, İÇAĞASIOĞLU, Arzu (2017). "Acil Servis Birimlerinde Sosyal Hizmet Uygulamaları", Tibbi Sosyal Hizmet, ed. Seda Attepe Özden ve Emre Özcan, ss. 159-170, Ankara: Nobel Yayıncılık.

DÖNMEZER, Sulhi (1994). Toplumbilim, İstanbul: Beta Yayınları.

DURKHEIM, Emile (1985). Toplumbilimsel Yöntemin Kuralları, çev. Cemal Bali Akal, İstanbul: BFS Yayınları. (1992). Intihar, çev. Özer Ozankaya, Ankara: İmge Yayınları. (2010). Dinsel Yaşamın İlk Biçimleri, çev. Özer Ozankaya, İstanbul: Cem Yayınları. (2014). Toplumsal İşbölümü, çev. Özer Ozankaya, İstanbul: Cem Yayınları.

ENGSTROM, Malitta (2006). "Physical and Mental Health: Interactions, Assessment, and Intervention", Handbook of Health Social Work, ed. Sarah Gehlert and Teri Arthur Browne, pp. 194-251, USA: New Jersey: John Wiley \&Sons Yayınları. 
Aziz ŞEKER, “Durkheim'in Sosyolojisinde İntihar ve İntiharla Mücadelede Sosyal Hizmetin İşlevi”, Mavi Atlas, 7(1)/2019: 90-110.

ERGUN, Doğan (1982). Sosyoloji ve Tarih, İstanbul: Der Yayınları.

ESKIN, Mehmet. (2003). Intihar, Ankara: Çizgi Tıp Yayınları.

FROMM, Erich (1996). Sağlıklı Toplum, çev. Yurdanur Salman, Zeynep Tanrısever, İstanbul: Payel Yayınları.

GEÇTAN, Engin (1994). Psikodinamik Psikiyatri ve Normal Dışı Davranışlar, İstanbul: Remzi Kitapevi.

GIDDENS, Anthony (2014). Kapitalizm ve Modern Sosyal Teori, çev. Ümit Tatlıcan, İstanbul: İletişim Yayınları.

KAĞITÇIBAŞI, Çiğdem (1988). İnsan ve İnsanlar, İstanbul: Evrim Yayınları.

KIZILÇELIK, Sezgin (1994). Sosyoloji Teorileri, Konya: Yunus Emre Yayınları.

KONGAR, Emre (1972). Sosyal Çalışmaya Giriş, Ankara: Sosyal Bilimler Derneği Yayınları.

KÖKNEL, Özcan (1987). Zorlanan İnsan, İstanbul: Altın Kitaplar Yayınları.

KÜPÇÜK, Yeliz, BÜYÜKKAYA, Eyüp vd. (2004). Intiharın Önlenmesi Birinci Basamak Sağlık Çalışanları Iç̧in Kaynak, çev. Tuğba Kurtuluş, Ahmet Tunç Demirtaş, Ankara: T.C. Sağlık Bakanlığı TSHGM.

MORGAN, Henry Lewis (1986a). Eski Toplum II. çev. Ünsal Oskay, İstanbul: Payel Yayınları.

(1986b). Eski Toplum 1. çev. Ünsal Oskay, İstanbul: Payel Yayınları.

ÖZCAN, Burcu, ŞENKAYA, Sevcan vd. (2018). “Türkiye'deki İntihar Vakalarının Çeşitli Kriterlere Göre İstatiksel Olarak İncelenmesi”, Sosyal Politika Çalışmaları Dergisi, 40, s.11-34

POLAMA, Margaret (1993). Çă̆daş Sosyoloji Kuramları, çev. Hayriye Erbaş, Ankara: Gündoğan Yayınları. 
Aziz ŞEKER, “Durkheim'in Sosyolojisinde İntihar ve İntiharla Mücadelede Sosyal Hizmetin İşlevi”, Mavi Atlas, 7(1)/2019: 90-110.

RITZER, George, STEPNISKY, Jeffrey (2014). Sosyoloji Kuramları, çev. Himmet Hülür, Ankara: Deki Yayınları.

SIMMEL, Georg (2009). Bireysellik ve Kültür, çev. Tuncay Birkan, İstanbul: Metis Yayınları.

SÜMER, Necati (2015). Dinlerin Intihar Olgusuna Bakışı, (Yayımlanmamış Doktora Tezi), Ankara Üniversitesi, Sosyal Bilimler Enstitüsü, Ankara.

ŞEKER, Aziz (2013). Toplumu Düşünmek, Ankara: Sabev Yayınları.

TIRYAKIAN, Edward (1997). "Emile Durkheim”, Sosyolojik Çözümlemenin Tarihi, ed. Nisbet, R. Bottomore, yaz.haz. Mete Tuncay/Aydın Uğur, böl.çev. Ceylan Tokoğlu, ss. 193-241, Ankara: Ayraç Yayınları.

ZASTROW, Charles, ASHMAN, Kirst (2016). Insan Davranışı ve Sosyal Çevre I, ed. Durdu Baran Çiftci, çev. Abdurrahman Aydın vd. Ankara: Nika Yayınevi.

\section{Internet Kaynaklar}

http://www.tuik.gov.tr/PreHaberBultenleri.do?id=18626 İntihar İstatistikleri, Türkiye İstatistik Kurumu, 2014 (Erişim Kasım 2018)

http://www.tuik.gov.tr/PreHaberBultenleri.do?id=24649 İntihar İstatistikleri, Türkiye İstatistik Kurumu, 2016 (Erişim Kasım 2018). 